\title{
De Minas Gerais à Rússia: Os modos de atuação em Moscou
}

\author{
Luíza Zaidan Granato ${ }^{1}$
}

A questão da representação sempre ocupou lugar de honra na obra do documentarista Eduardo Coutinho. Desde a primeira tentativa de realizar Cabra Marcado Para Morrer, quando o Golpe Militar de 1964 interrompe as filmagens e atrasa em vinte anos a finalização do longa, o projeto já era o de trabalhar com atores não profissionais, selecionados em um casting para representar o assassinato do líder campesino João Pedro Teixeira. No roteiro original, a própria esposa do personagem, Elizabeth Teixeira, interpretaria a si mesma - mas outra cidade foi escolhida para servir de palco para a versão ficcionalizada da história e um morador local foi selecionado para interpretar o papel de João. De certa maneira, Coutinho testava em Cabra um método já formulado por Robert Flaherty em experiências como O Homem de Aran (1934), quando o diretor escolheu um ferreiro que morava na vila onde aconteceram as filmagens para dar vida ao protagonista do documentário sobre a cultura da pesca na ilha de Aran. O ator não profissional de Flaherty não era pescador, como a personagem, e chegou a precisar usar um dublê em algumas cenas, tal qual um ator de Hollywood que tem de aprender certo repertório de ações para compor o jogo naturalista.

A problemática da representação cotidiana sempre foi cara a Coutinho e é elemento constitutivo de sua cinematografia. O diretor sabia que a simples presença da câmera altera o comportamento do sujeito que ela filma: "Na medida em que a pessoa pode representar para a câmera, isso passa a ser interessantíssimo também. Como ela representa para a câmera? Que papel? Que figura? E que personagem ela quer representar para a câmera?" (Coutinho 2013, 23). Trata-se da possibilidade de estabelecer um pacto entre "sujeito filmante" e "sujeito filmado 2 ", garantindo espaço para a autorrepresentação.

Nesse ponto da reflexão, uma questão se coloca como norteadora do confronto com a obra de Coutinho: de que forma o modo como a personagem se autorrepresenta determina a mise-enscène de seus documentários? No livro Ver e Poder, Jean-Louis Comolli investiga o mecanismo através do qual o "sujeito filmado" produz sua própria mise-en-scène e o modo como isso conflui para

\footnotetext{
${ }^{1}$ Instituto de Artes/Universidade Estadual de Campinas, CEP 13083-854 Campinas, SP, Brasil.

2 Termos utilizados por Jean-Louis Comolli para descrever a relação entre realizador e personagem, durante as filmagens de um documentário (Comolli 2008).
} 
uma construção compartilhada da mise-en-scène do filme, ampliando a discussão.

A teoria e a crítica cinematográficas dedicam grande espaço à análise da mise-en-scène na ficção. No entanto, pouco se fala sobre como se dá essa construção da cena na bibliografia sobre o documentário. Em ensaio para a revista Rebeca, Fernão Pessoa Ramos aponta um caminho:

É nas especificidades do movimento e da expressão do corpo em cena, nas diversas modalidades de interação com o sujeito que sustenta a câmera, que recortaremos o conceito de mise-en-scène para articulá-lo ao campo documentário. É na ação do corpo em cena, do corpo-sujeito da tomada (para e pela câmera, lançando-se, enquanto imagem futura, ao espectador e sendo por ele determinado), que iremos atingir o coração da mise-en-scène para fazê-lo pulsar dentro da estilística documentária $(2012,21)$.

Para compreender o meio pelo qual Coutinho estabelece a relação com as personagens e deixa que esta conforme a mise-en-scène de seus documentários, faz-se necessária uma análise do encontro entre realizador e ator-personagem, ao longo de sua filmografia. No ensaio Aqueles que filmamos: notas sobre a mise-en-scène documentária, Comolli interroga-se sobre dois lados de uma mesma moeda: "Como a câmera atua com aqueles que ela filma? E como eles atuam com ela?" (2008, 52). O autor explica que, devido à massificação dos recursos audiovisuais, mesmo quem nunca foi filmado tem uma ideia do que esse ato representa e isso condiciona o modo como se posiciona diante de uma câmera. Durante a produção de um documentário, o sujeito filmado propõe um dispositivo do qual também é responsável. Comolli define a mise-en-scène como "um fato compartilhado, uma relação. Algo que se faz junto e não apenas pelo cineasta (...). Aquele que filma tem como tarefa acolher as mise-en-scènes que aqueles que estão sendo filmados regulam" (2008, 60).

A relação entre o "sujeito filmante" e o "sujeito filmado" ganha complexidade quando a analisamos à luz do conceito de auto-mise-enscène ${ }^{3}$ criado pela pesquisadora Claudine de France no contexto da antropologia fílmica e, posteriormente, deslocado para os estudos documentais por Comolli. O sujeito filmado observa a presença daquele que o filma e se apresenta para o encontro, trazendo seus hábitos, gestos, reflexos e posturas que impregnam as circunstâncias da filmagem. Esse processo pode ocorrer de forma consciente ou inconsciente, mas é sempre um elemento determinante ${ }^{4}$. Em obras

\footnotetext{
3 "Noção essencial em cinematografia documentária, que define diversas maneiras pelas quais o processo observado se apresenta por si mesmo ao cineasta no espaço e no tempo. Trata-se de uma mise-en-scène própria, autônoma, em virtude da qual as pessoas filmadas mostram de maneira mais ou menos ostensiva, ou dissimulam a outrem, seus atos e as coisas que as envolvem, ao longo de atividades corporais, materiais e rituais. A auto-mise-en-scène é inerente a qualquer processo observado." (France 1998).

${ }^{4}$ No livro Cinema e Antropologia, encontram-se as bases metodológicas para o trabalho do etnólogo-cineasta. France compreende a produção audiovisual como
} 
como as de Eduardo Coutinho, a mise-en-scène declarada (aquela determinada pelo diretor) acaba se atenuando para abrir espaço à auto-mise-en-scène da personagem, o outro com quem se dá a relação.

Para Coutinho, o que interessa são as histórias imaginárias das personagens com quem se encontra. Citando como referência teórica para seu trabalho o livro A Representação do Eu na Vida Cotidiana, do sociólogo Erving Goffman, o cineasta reforça que não há um "eu" verdadeiro, se não aquele representado nas diversas situações sociais. Essa ideia desloca o pensamento sobre atuação da dualidade verdadeiro/falso, valores que, segundo Goffman, variam de acordo com a crença do sujeito em sua própria representação e na maneira como ele escolhe gerenciá-la. Em Edifício Master (2002), o cineasta pergunta a Alessandra, uma das entrevistadas, se ela costuma mentir. A personagem declara ser uma mentirosa verdadeira e que quanto mais acredita em suas mentiras mais credibilidade elas passam a ter. Intuitivamente, ela passeia pela ideia de teatralidade ${ }^{5}$ e da produção de autenticidade na representação. Em sua análise, Ismail Xavier compara: "Essa ênfase na ideia do sujeito da fala 'acreditar' no que diz corresponde ao movimento de assumir um personagem para quem o conteúdo da sua narração é a verdade" (2013, 612).

Para Goffman, "nosso personagem deliberado é mais verdadeiramente nós mesmos que o fluxo de nossos devaneios involuntários" (2001, 58). Além disso, o autor aborda a ideia de "impressão de realidade", conceito que legitima a representação cotidiana, gerando uma sensação de veracidade, dotada de caráter frágil, que pode ser quebrada por pequenos contratempos que se impõem durante a representação.

Portanto, para confrontar-se com esse "verdadeiro", faz-se fundamental abrir espaço para a representação no documentário. Ela está presente em diversos momentos da obra de Coutinho, como na passagem de Cabra marcado para morrer (1984), em que João Virgínio encena como passou 24 horas de pé, dentro de um tonel "cheio de merda”, na ocasião em que foi preso pela ditadura militar. $\mathrm{Na}$ profundidade do quadro, vemos um projetor usado para exibir as imagens captadas em 1964, mas também para lembrar ao espectador que aquilo é cinema e que João é ator (ainda que não profissional),

ferramenta para a pesquisa etnográfica, capaz de ampliar seu potencial de observação. É nesse contexto que a autora cunha o termo auto-mise-en-scène: a escolha do cineasta de quais aspectos sublinhar ou esfumar no registro de um ritual, por exemplo, estaria submetida a uma capacidade de organização interna do evento observado. Em contrapartida, France indica que esse "auto-sublinhamento dos processos observados tem assim apenas um valor de produto semiacabado que pede que seja finalizado através de uma mise-en-scène do cineasta que lhe confirmaria os traços. É assim que deve ser entendida toda relação de coincidência entre a automise-en-scène do processo observado - em virtude da qual as pessoas filmadas sublinham por si mesmas certos aspectos ou certas fases de sua ação - e a mise-enscène do cineasta" (1998, 47). Portanto, Comolli se aproxima novamente das teorizações de France ao apresentar a noção de mise-en-scène compartilhada.

5 Josette Féral "define teatralidade como uma condição que transcende o teatro, manifestando-se em distintas situações da vida social e do cotidiano” (apud Xavier 2013, 609). 
representa um papel. Ele se apoia em um poste, se vira de lado, tosse, cospe e sorri, se valendo de gestos teatralizados para reativar sua memória e dar corpo ao seu relato. No fora de campo, ouve-se a risada de Coutinho, divertindo-se com a encenação irônica do homem que fabula a personagem de si mesmo. Fragmentos como esse apontam para o modo como a mimese e a diegese já conviviam em seus filmes ${ }^{6}$, mesmo na primeira fase da carreira do cineasta: a personagem coutiniana se vale da imitação do gesto, da voz e das palavras para 'mostrar' uma imagem de si - mas uma imagem que corresponde também a uma versão ficcional da narrativa, ligada ao ato de 'contar'.

As personagens de Coutinho atuam para a câmera. Das mais diferentes formas, de modo discreto ou escancarado. Ao longo de sua carreira, o diretor desenvolveu um modo particular de relacionar-se com os atores-personagens e colocou seu método à prova diversas vezes, até chegar a Jogo de Cena (2007), quando assume a investigação dos limites da representação em um caminho que passou por Moscou (2009) e acabou desaguando em As Canções (2011). Nos três documentários, Coutinho pode refletir sobre o lugar da autorrepresentação e do trabalho do ator profissional, em paralelo ao comportamento do sujeito comum que oferece sua imagem à câmera. Cada um desses documentários, realizados em sequência, carrega questões que se colocam desde a obra pregressa e, ao mesmo tempo, apontam para desdobramentos que ecoam no filme seguinte. Analisálos em conjunto significa compreender o discurso que vai além de cada obra, delimitando a existência de uma trilogia que o pesquisador Fábio Andrade batizou de "trilogia do palco" (2013, 649-657).

Nos dois primeiros filmes dessa trilogia, Coutinho recorre ao trabalho de atores profissionais (vindos do teatro, de pequenas figurações na televisão ou até do estrelato nas novelas, no caso de Jogo de Cena) para confrontar suas performances com a dos atores não profissionais, que sempre povoaram a obra do cineasta. Qual é a relação entre a postura do ator, que assume uma personagem e deposita sua fé nas circunstâncias ficcionais da cena, e uma pessoa que representa a si mesma diante da câmera do documentarista? O que acontece quando o "sujeito filmado" é um ator profissional, acostumado a produzir sua própria imagem e seu jogo de representações através da chave da ficção, mas que, dessa vez, precisa fazê-lo dentro do domínio do documentário? O que há de artificialidade no discurso da personagem documental e o que há de verdadeiro no papel do ator? O relato de uma memória cotidiana vira texto ficcional na boca da atriz que o interpreta, acrescentando a ele

6 Trabalhamos aqui com a noção aristotélica de mimese para designar a ação de imitar que, segundo o filósofo, contempla o fundamento de toda arte, mas é também inerente a diversos procedimentos da atividade humana. Trata-se da ideia de imitação como forma de representação do mundo. Para Aristóteles, ao recontar um fato o poeta pode atingir a universalidade através da capacidade de imitação: "O poeta conta, em sua obra, não o que aconteceu e sim as coisas quais poderiam vir a acontecer e que sejam possíveis tanto na perspectiva de verossimilhança como da necessidade" $(2000,47)$. Assim, podemos notar esse caráter mimético no modo como as personagens coutinianas representam sua realidade dentro do texto fílmico. 
novas camadas: os traços deixados pelo oficio do ator, ou as marcas de uma persona, às vezes conhecida do grande público. Trata-se de diferentes modos de atuação que passaram a coexistir nos filmes de Coutinho.

\section{Os Modos de Atuação}

No livro Acting in the Cinema, James Naremore introduz a questão do jogo cênico, apresentando uma análise do filme Corrida de Automóveis para Meninos (Henry Lehrman, 1914), quando Charlie Chaplin inaugura seu Carlitos em um quadro cômico no qual o personagem atrapalha uma equipe de filmagem que tenta registrar um evento de rua. Naremore estabelece uma diferenciação entre o jogo assumido (o trabalho de Chaplin, ator profissional) ao qual se refere como "jogo teatral", e o "jogo aleatório", o comportamento dos transeuntes que testemunhavam a corrida e acabaram participando do filme. Essa segunda modalidade se relaciona diretamente à ideia de Erving Goffman de que todo mundo, em qualquer situação social, representa um papel. Naremore recupera outro conceito do sociólogo, presente no livro de 1974, Frame Analysis. Trata-se da ideia de "moldura", que diferencia as respostas a cada interação social. Uma espécie de ritual de sinalização aos participantes da interação para que diagnostiquem a atuação de caráter teatral e aquela cotidiana, típica das relações intersubjetivas. Naremore estabelece alguns níveis de jogo no filme de Chaplin e declara que a comicidade se dá justamente através do reconhecimento, por parte do espectador, das nuances entre esses modos de atuar, percebidos de maneiras distintas. Ele sugere que "as pessoas, em um filme, podem ser vistas em três diferentes sentidos: como atores interpretando personagens, teatralmente; como figuras públicas fazendo versões teatrais de si mesmos; e como evidências documentais"7 $(1988,15)$. Assim, a ideia de jogo estaria contemplada por essas três modalidades.

Em Moscou, alguns aspectos dessas formas de atuação se encontram presentes na estrutura narrativa. A pedido de Coutinho, o grupo de teatro Galpão se dedica aos ensaios, para uma montagem que nunca chegaria a acontecer, da peça As Três Irmãs, de Anton Tchekhov. O documentário acompanha o processo guiado pelo diretor Enrique Diaz e o trabalho dos atores em contato com o texto russo. Depois de refletir sobre seu próprio método, em Jogo de Cena, Coutinho dá continuidade a sua busca pelos modos de representação.

O documentário se estrutura através da experiência do ator, que encena a si mesmo e a uma personagem ficcional. Diversas vezes, o espectador é convidado a invadir o camarim e a acompanhar o elenco, estudando o texto, descansando ou comendo, nos intervalos dos ensaios. A câmera na mão (quase ausente nos últimos filmes de Coutinho) parece bisbilhotar, a todo tempo, tanto a intimidade dos atores quanto a solidão das personagens russas. A mistura de cenas de bastidores com os exercícios cênicos em cima da dramaturgia de

\footnotetext{
${ }^{7}$ Todas as traduções de textos no original foram feitas, livremente, para este artigo.
} 
Tchekhov permite ao espectador entrar e sair diversas vezes do universo da ficção, que vai se construindo por meio das improvisações do grupo, ao longo do processo registrado pelo documentário.

Além dos procedimentos de estudo do texto, em trabalhos de mesa típicos de um processo teatral, o documentário revela os exercícios propostos por Enrique Diaz, geralmente calcados no uso de fragmentos da memória dos atores. Logo no início do filme, um primeiro plano do diretor enuncia a atividade: cada ator deve se apresentar e dividir com o grupo uma questão com a qual esteja se debatendo, uma imagem do passado e uma imagem do futuro. Como é comum na rotina de algumas companhias (em geral respaldados pelos preceitos do método Stanislavski), o elenco trabalha com seu repertório pessoal para cavar um espaço de sensibilização interna, onde possam ecoar os conflitos apontados pelo dramaturgo russo. Aqui, confluem ao menos duas formas distintas de jogo: ao mesmo tempo que a atriz Inês Peixoto repete as falas de Olga, a mais velha das três irmãs da peça de Tchekhov, ela também vasculha em sua infância, em busca da lembrança de quando escondeu uma caixa de bombons para tentar criar seu espaço privado, em uma casa povoada por onze irmãos.

Neste ponto, o trabalho de Constantin Stanislavski ajuda a compreender o tipo de encenação proposta em Moscou. Em seus estudos, o diretor russo, que teorizou as formulações do teatro Realista, aborda a ideia de que o ator poderia reviver sentimentos, através de estímulos interiores e exteriores, para compor a personagem. Compreende-se que, mesmo encenando um papel, o ator interpreta a si mesmo, variando entre uma infinidade de objetivos e circunstâncias dadas pela dramaturgia e revolvendo nos escombros da sua memória afetiva ${ }^{8}$. Mecanismo não muito diferente é aquele experimentado por um ator não profissional, colocado em situação diegética quando se dispõe a contar-se diante da câmera. Ao compartilhar um capítulo de sua vida, uma personagem documental deve recuperar certos aspectos dessa experiência, retomando gestos e feições construídos para provocar, no espectador, a materialização daquele episódio compartilhado. Ainda que se utilize de uma atuação apresentacional (contando, no presente, a experiência vivida no passado), o ator não profissional, inconscientemente, flerta com os procedimentos stanislavskianos ao trazer para a construção de seu jogo a rememoração de uma vivência que já ficou para trás.

Em seu livro, Naremore aponta para duas maneiras de atuar: o trabalho do ator profissional, que representa uma personagem ficcional, e a personalidade que aparece no filme interpretando a si mesma. Os integrantes do grupo de teatro de Minas Gerais estão

8 "Esse tipo de memória, que faz com que você reviva as sensações que teve outrora (...) é o que chamamos de memória das emoções ou memória afetiva. Do mesmo modo que sua memória visual pode reconstruir uma imagem interior de alguma coisa, pessoa ou lugar esquecido, assim também sua memória afetiva pode evocar sentimentos que você já experimentou. Podem parecer fora do alcance da evocação e eis que, de súbito, uma sugestão, um pensamento, um objeto familiar os traz de volta em plena força” (Stalislavski 2011, 207). 
sempre representando diante da lente de Coutinho (porque são atores profissionais, mas também, e principalmente, porque são homens e mulheres colocados em dinâmicas sociais nas quais, de acordo com Goffman, a representação é inerente). Examinadas lado a lado, as duas atuações de Inês Peixoto são distinguíveis graças ao efeito de "moldura", explicado por Goffman e retomado por Naremore. A maneira como ela mexe as mãos, a segurança de sua voz e certa impostação denunciam o trabalho da atriz profissional (o "jogo teatral"), em suas aparições como Olga. O mesmo acontece em Corrida de automóveis para meninos: "O próprio Chaplin faz certas coisas para nos informar que é um homem que finge ser um bêbado, exibindo uma imagem ao invés de ser a coisa em si” $(1988,16)$. Sua movimentação, seu figurino e uma série de elementos indicam o "jogo teatral". No entanto, encontramos outra Inês Peixoto nos momentos em que a atriz interpreta a si mesma, na lógica do "jogo aleatório". Ainda que ela siga consciente de sua representação, seus depoimentos pessoais são revestidos de certo tom confessional, uma maior impressão de intimidade, ao mesmo tempo que ela faz pausas em seu discurso, relembrando os pormenores das memórias que compartilha com o grupo e com o espectador. Ela parece evitar o contato direto com a câmera, buscando com o olhar a cumplicidade dos colegas que a escutam, fora de campo. Despida da personagem ficcional, escudo que pode trazer segurança ao ator, ela oferece sua própria história para servir de matéria à narrativa. Assim, faz parte da fruição do espectador caçar as nuances presentes nas diferentes formas de atuar reveladas no filme.

\section{A "encenação direta"}

Em Moscou, Inês Peixoto atua como personagem de Tchecov e também como personagem coutiniana. As nuances entre esses diferentes modos de atuação estão no grau de consciência envolvido em cada jogo e na forma como ela os gerencia. No artigo "A Mise-enscène no documentário”, Fernão Pessoa Ramos defende a importância de delinear o lugar da encenação dentro do domínio do documentário e enfatiza a relação entre o "sujeito-da-câmera" e o mundo que a ele se oferece. É justamente essa relação que o autor denomina de encenação documentária:

A ação do corpo na tomada e a expressão de seu afeto pela fisionomia e pelo gestual constituem o umbigo da especificidade da encenação documentária, que se constela concretamente (se afigura) no tempo presente, no transcorrer do presente enquanto franja de um acontecer. $(2012,21)$

Assim, a mise-en-scène se determina pela forma como essa encenação se dispõe na filmagem, considerando os vários aspectos materiais (inclusive o trabalho do ator) que compõem a cena e sua posterior organização narrativa. 
O corpo que encena, encena para alguém (mesmo quando a instância da recepção é ignorada, ao se optar por camuflar o processo de atuação, no caso de filmes que operam dentro da lógica da transparência). No documentário, encena para a presença concreta do sujeito que filma e para a presença futura do espectador. Comolli aponta para essa interação entre os corpos do "sujeito filmante" e do "sujeito filmado", no momento do encontro:

Aquele que eu filmo me vê. Quem diz que não pensa o seu olhar para mim, assim como penso meu olhar para ele? A consciência é necessariamente algo que se passa entre as consciências. O inconsciente, entre os inconscientes. O corpo, entre os corpos. Aquele que eu filmo me chega não somente com sua consciência de ser filmado, sua concepção do olhar, ele chega com seu inconsciente em direção à máquina cinematográfica, ela própria carregada de impensado, ele chega com seu corpo diante dos corpos daqueles que filmam. $(2008,84)$

Segundo Ramos, durante a tomada, a presença do "sujeito-dacâmera" transforma a ação do "sujeito filmado" em representação. Enquanto isso, ao comandar o dispositivo, o próprio "sujeito-dacâmera" encarna uma personalidade, que pode ou não ser evidenciada na obra, mas não deixa de ser um fator determinante.

Ao destrinchar esse jogo de relações entre as instâncias envolvidas na experiência fílmica, Ramos descreve dois tipos de encenação:

Olhando para a história do documentário, podemos notar duas variantes estruturais na ação das pessoas para o sujeito-da-câmera: 1) chamamos de encenação-construída a ação ou expressão que é preparada, de modo anterior, pelo sujeito-da-câmera; 2) chamamos de encenação-direta a ação para a câmera solta no mundo, sem uma flexibilização direta pelo sujeito-da-câmera. $(2012,17)$

É possível articular uma relação entre essas duas formas de encenação, propostas por Ramos, e as modalidades de jogo delimitadas por Naremore: o "jogo aleatório" estaria circunscrito dentro da ideia de "encenação-direta", aquela na qual aparece amenizada a interferência do realizador; enquanto que o "jogo teatral", encontraria seu lugar dentro da "encenação-construída", admitindo um maior grau de consciência na arquitetura da ação. Em Moscou (assim como em seu antecessor, Jogo de Cena), estão presentes essas formas de encenação, que interagem e conformam a estrutura narrativa do filme.

Ramos segue explicando que o corpo do ator carrega uma camada de densidade psíquica (a que ele chama de "personalidade"), que pode mostrar-se para a câmera em maior ou menor grau. Para o autor, o documentário contemporâneo tem revelado um especial interesse nessa camada de atuação que escapa do corpo filmado, se exibe e atua para o "sujeito-da-câmera". Desse mecanismo emergem, por exemplo, os métodos de escolha de sujeitos que saibam interagir 
com as circunstâncias da filmagem e sustentar uma personagem, por meio de sua fisicalidade, seus gestos e de seu olhar lançado, através da mediação da câmera, para o espectador. Essa "personalidade" não corresponde precisamente à pessoa a quem ela pertence, uma vez que surge apenas no momento do encontro com o realizador, diante das lentes. Deslocando o pensamento de Ramos para os estudos atorais, essa "personalidade", pode ser chamada de "persona", a camada da autorrepresentação manejada pelo ator profissional diante da câmera ou em situações sociais. No livro $O$ Ator de Cinema, Jaqueline Nacache descreve: "A notoriedade do ator estrela privilegia uma dinâmica atorpersona, em detrimento da relação ator-personagem. Qualquer ator conhecido traz consigo um subtexto composto de personagens que tocou ou que o tocaram" $(2012,88)$. É o que acontece com os atores do grupo Galpão ao interpretarem a si mesmos, em Moscou, ainda que muitos deles não sejam propriamente "estrelas", mas sim atores de teatro habituados a representar dentro da lógica da ficção.

A "encenação-direta", segundo Ramos, não se determina de modo arquitetado, decupado previamente. A encenação, nesse caso, é a ação que emerge espontaneamente da interação ativa entre as instâncias que vivenciam a experiência do encontro, no momento da filmagem. Através da chave da "encenação-direta”, "[p]essoas transformavam-se facilmente em personagens, flexionadas pela presença do sujeito-da-câmera, cuja carne presente dava espessura à vida ordinária numa espécie de 'mundanidade' ordinária” (2012; 28).

Pensando na aplicação da perspectiva de Ramos à análise do documentário Moscou, como se articularia o conceito de "encenaçãodireta" com a postura do ator profissional, que encena também a si mesmo (de modo teatral), em tantos momentos do filme? Existe espaço para a "encenação-direta" em Moscou, ou o jogo de representação assumido, deflagrado pela revelação dos mecanismos de construção tanto da peça (uso de figurinos; presença da dramaturgia materializada no texto impresso que os atores carregam em mãos) quanto do documentário (presença frequente da equipe e equipamentos no quadro), impede esse tipo de encenação não controlada?

A fabulação dos atores como personagens de si mesmos é justamente a camada que faz transparecer a "encenação-direta" no filme. Em alguns momentos, quando estão lanchando ou se preparando para entrar em cena, os atores do grupo Galpão encenam de forma direta, conformam uma personagem que difere daquilo que são cotidianamente, longe das câmeras de Coutinho. Ao compartilhar uma memória que lhe pertence, a atriz Inês Peixoto não estaria representando, tanto quanto quando aparece interpretando a personagem Olga? Goffman diria que sim, já que o trabalho em grupo na sala de ensaio e o encontro com Coutinho configuram situações sociais nas quais a representação é inevitável. Além disso, os procedimentos de criação de um grupo de teatro e a presença da câmera catalisam e acentuam ainda mais o aspecto da representação. 
Para Ramos, a "encenação-direta” presente nos documentários (que ganha maior fôlego nas produções a partir dos anos 1960) incorpora um tipo de agir que se dá apenas durante a circunstância da filmagem e configura-se de maneira diferente da postura que o sujeito assume no mundo.

Nós somos, no mundo, segundo a circunstância, em adequação ao que consideramos a essência da personalidade de nosso ser e a demanda do mundo sobre ele. Isso seria também encenação? Se enceno o professor quando dou aula, se enceno o pai quando estou com meu filho, se enceno o chefe quando distribuo tarefas, o conceito de encenação amplia seu horizonte e confunde-se com estar no mundo. O tipo de ação que se desenrola livre no transcorrer indeterminado da tomada é próprio a um estilo cinematográfico que embasa uma forma narrativa e que estamos chamando de "direto". (2012, 27)

A noção de encenação confundida com o estar no mundo se relaciona com o conceito de representação cotidiana de Goffman. No livro de 1959, o sociólogo define o conceito de representação como sendo referente a "toda atividade de um indivíduo que se passa num período caracterizado por sua presença contínua diante de um grupo particular de observadores e que tem sobre estes alguma influência" (2001, 29). O autor defende a necessidade de um pacto que se estabelece entre o indivíduo que desempenha um papel e seus observadores, que levam a sério a impressão sustentada perante eles (pacto não muito diferente daquele que rege a relação entre atorpersonagem, realizador e, por extensão, espectador de um documentário).

Na sequência, o autor tece uma análise dos modos pelos quais se dão as representações cotidianas, como são moldadas para se ajustar às compreensões e expectativas da sociedade em que são apresentadas. Os atores (palavra que Goffman usa para designar qualquer sujeito que age, dentro da lógica da representação cotidiana) oferecem, portanto, uma impressão idealizada aos seus observadores, adequando a concepção da representação a cada situação social. Em resumo, todos os sujeitos, nas mais diferentes situações do cotidiano, interagindo em qualquer relação, representam utilizando seus equipamentos de sinais e correspondendo a determinadas expectativas de seu público. A "coerência expressiva", demandada pelas representações, sublinha a distância entre nosso aspecto humano essencial e nosso eu socializado, nossa autorrepresentação. Trata-se dos conflitos que se estabelecem entre "o que eu penso de mim" e "aquilo que eu quero que os outros pensem" e como essas duas instâncias constituem uma visão de si. Naremore também recupera a noção de "coerência expressiva", partindo de Goffman, para abordar o modo como a atuação profissional, de certa maneira, copia a atuação cotidiana que, por sua vez, é uma reprodução das demais atuações cotidianas que a cercam:

A vida cotidiana geralmente exige que mantenhamos uma coerência expressiva, garantindo aos outros nossa sinceridade; teatro e cinema funcionam de acordo com um princípio mais complexo, 
frequentemente exigindo que os atores dramatizem situações em que a coerência expressiva de um personagem se rompe ou se revela como uma mera "atuação". $(1988,70)$

Goffman fala sobre os pequenos contratempos que surgem durante a representação, que podem romper o pacto com os observadores e colocar sua credibilidade em risco. Em Moscou, alguns imprevistos da improvisação também desequilibram o universo ficcional da peça As Três Irmãs. Em um intervalo nos ensaios, o elenco aproveita para "bater o texto", enquanto faz um lanche na companhia do diretor e da equipe do documentário. Fernanda Viana e Eduardo Moreira treinam as falas da cena em que os amantes Macha e Vechinin declaram seu amor proibido. O personagem russo está irritado e Moreira ataca, certeiro, na fala que justifica seu mau-humor: “Também, eu não comi nada hoje”. Só que, nas circunstâncias concretas do momento da interação (um ensaio informal, nos bastidores do teatro), o ator estava mordiscando um salgadinho e a contradição gera um ruído em sua representação. No extracampo, ouvem-se as risadas do elenco que percebe a ruptura do pacto e a afirmação da verdade da situação sobre o contexto da ficção: trata-se de dois atores mineiros, treinando suas falas, durante uma pausa na jornada de trabalho e não dois apaixonados que conversam às escondidas, no interior da Rússia.

O mesmo tipo de incidente é revelado na cena em que Macha sobe uma escada instável, vestindo asas de anjo. Na tela, vê-se seu rosto em primeiro plano, mas é possível ouvir, no extracampo, as expressões de susto do restante da equipe que assiste a cena. O enquadramento seguinte, um plano aberto, mostra que outros atores correm para socorrê-la quando a escada se desequilibra, lembrando a todos que aquela não é Macha, a irmã do meio que se debate com um casamento infeliz, na ficção, mas sim a atriz Fernanda Viana, que pode chegar a se machucar com as possíveis falhas na representação. $O$ fator de risco (inclusive o risco físico), a fragilidade da representação, sempre foram elementos atrativos no campo da encenação.

\section{A "encenação construída"}

Ramos credita os procedimentos da "encenação-construída" no documentário principalmente à escola inglesa, liderada por John Grierson e Paul Rotha nos anos de 1930. Elementos como o uso da voz over e, mais tarde, o uso de imagens de arquivo e a reconstituição de eventos históricos (com atores profissionais e cenários construídos em estúdio) definiram um tipo de mise-en-scène bastante estruturado, no estilo estético que dominou a primeira metade do século passado e figura até hoje.

A “encenação-construída”, como definida por Ramos, é fechada aos fatores de indeterminação que surgem durante o momento da filmagem: 
A encenação-construída no documentário trabalha a tomada por meio da preparação prévia e sistemática da cena, envolvendo nesse planejamento as falas, a movimentação dos corpos e da câmera, a fotografia, a cenografia, o roteiro, a decupagem. Enquanto a encenação-direta cavalga na indeterminação do transcorrer, explorando-o como forma de estilo, a encenação-construída age no modo fechado da previsibilidade, dentro de unidades "plano" que a composição narrativa demanda previamente de modo mais rígido. $(2012,31)$

A "encenação-construída", determinada pelo diretor, pode valer-se do trabalho de atores profissionais ou amadores, e até de pessoas que vivem próximas ao universo representado pelo documentário (como o homem escolhido para representar João Pedro Teixeira, no roteiro original de Cabra Marcado para Morrer). E essas camadas de atuação podem coexistir, em casos como o de Jogo de Cena.

O corpo que encarna a ação construída na tomada não age em si: expressa-se para a câmera, mas dentro de modalidades de ações antevistas que lhe são determinadas a priori, a partir de traços já levantados da personalidade de outrem. $(2012,31)$

Mas como é possível determinar esse grau acentuado de planejamento, se mesmo a "encenação-construída" precisa lidar com os fatores instáveis de qualquer circunstância de filmagem? Onde pulsam a imprevisibilidade e o erro dentro das estratégias da "encenação-construída"? Ou os contratempos da representação estariam relegados apenas ao campo indefinido da "encenaçãodireta"? Por ter o humano como matéria-prima, a tomada exala sempre um caráter de imprevisibilidade que a torna viva, mesmo quando essa vida emerge do trabalho, planejado e dirigido, de um ator profissional. A reflexão caminha, portanto, no sentido de compreender a escolha por um maior ou menor grau de interferência e controle, por parte do realizador, que pode passear entre uma escala de elementos da "encenação-direta" e da "encenação-construída". Ramos tece, de forma resumida, um percurso entre esse leque de modalidades de encenação:

O conceito de encenação, portanto, não pode ser visto de modo uniforme na história do documentário. Tudo se tornaria encenação, seja no documentário, seja na ficção. Não se pode colocar no mesmo patamar uma encenação em estúdio e uma leve inflexão de voz provocada pela presença da câmera. Os atos de encenação dos três habitantes de Aran que, sem nenhum vínculo de parentesco, interpretam uma família nuclear, surgiriam como equivalentes as atitudes "afetadas" de Edith e Edie Beale em Grey Gardens (Albert e David Maysles, 1975), ou de Luiz Inácio Lula da Silva em Entreatos (João Moreira Salles, 2004), ou ainda de Robert Kennedy em Primary (Robert Drew, 1960). Não podemos dizer que Lula, Kennedy ou Edie Beale encenam para a câmera como encena o pequeno garoto, que faz o filho que não é, em $O$ Homem de Aran. Lula, Kennedy e Edie encenam o que são em si mesmos. $(2012,36)$ 
Assim, é possível ir além, afirmando que Lula, Kennedy e Edie Beale estariam ranqueados bem no meio da escala de construção da encenação, uma vez que não representam uma personagem, mas sim suas personas, representam a si mesmos.

Em Moscou, "encenação-direta" e "encenação-construída" conversam de diversas maneiras. E essa interação está presente desde a premissa do filme: Coutinho não se propõe apenas a observar os bastidores de uma companhia de teatro em seus processos corriqueiros, com uma dinâmica de making of. É o diretor que interfere na realidade, convidando o grupo Galpão a ensaiar uma peça que nunca entraria em cartaz, em três semanas de trabalho que tinham como única finalidade a produção do documentário.

Na primeira vez que vemos o grupo reunido em volta da mesa de trabalho, Coutinho explica a proposta para os atores convidados: montar trechos da peça As Três Irmãs, objetivando "o inacabado fragmento". Enrique Diaz complementa, explicando que não seria possível finalizar o trabalho e que é preciso priorizar aquilo que pertence ao reduto do humano, no texto. Ele indica que o procedimento seria o de expandir o universo do dramaturgo russo, mas também construindo algo a partir dessa exploração. Dessa forma, as regras do jogo são enunciadas e se acende um foco sobre o próprio processo de construção, abrindo mão de mostrar a obra construída, o produto final. A partir daí, o elenco inicia uma primeira leitura do texto, enquanto a voz over de Coutinho situa o espectador na trama da família Prozorov. A montagem esclarece qual ator será designado a qual papel, na maior parte do filme, associando seus primeiros planos aos nomes das personagens, narrados pelo cineasta.

O documentário prossegue em um mergulho cada vez mais profundo na "encenação-construída": conforme o processo de ensaios avança, o espectador vai sendo levado de Minas Gerais à Rússia, dos fragmentos de memória dos atores ao contexto das personagens de As Três Irmãs, em um movimento de entrada e saída na trama da peça. As escolhas dos figurinos e cenários, o aquecimento do jogo improvisacional vão tecendo os elementos de construção do mundo fictício, que se ergue no palco e na tela do documentário.

Os rastros dos atores que encenam a si mesmos e a construção das personagens fictícias se misturam, frequentemente, nos signos que compõem o documentário. Diversas vezes o elenco aparece trajando figurinos que caracterizam suas personagens, mas levam suas fotografias da infância pregadas ao corpo. O mesmo acontece na sequência de respostas do elenco ao exercício proposto por Enrique Diaz: ao evocar suas imagens pessoais de passado e futuro, os atores tocam em temas tão centrais à obra de Tchekhov como o nascimento, a finitude, a morte, a solidão e relacionamentos familiares desfeitos. Uma impressão de realidade domina a tônica desses depoimentos, que parecem atender à lógica da "encenação-direta", mas, ao mesmo tempo, partem de uma proposição externa bem programada e definida. Já as cenas de outro exercício, em que os atores misturam 
fotos de família (circunstâncias pessoais) com os nomes das personagens fictícias, revelam uma impressão de teatralidade e deixam claro o caráter de construção na encenação, provavelmente elaborada, a priori, pelos próprios atores para apresentar ao resto do grupo.

É possível acompanhar, em Moscou, a evolução na arquitetura da cena. $\mathrm{O}$ espectador entra em contato com a repetição de diálogos em diferentes contextos, seguindo o amadurecimento que sai do estudo do texto, durante o trabalho de mesa, passa pelos intervalos de ensaio, pelo camarim, até chegar ao palco, quando a ficção de Tchekhov prevalece sobre o trabalho do ator. No entanto, o caráter reflexivo do documentário logo volta a revelar um plano enquadrado através da imagem do video assist ou um resto de marcenaria que sobrou da construção de algum cenário, relembrando o espectador de que tudo é processo, na peça e na obra de Coutinho.

A cena final do documentário retorna à situação do trabalho de mesa. O enquadramento começa fechado em um plano conjunto das irmãs Irina e Olga, que conversam sobre o desejo de mudar-se para Moscou, em seus últimos lampejos de esperança. Pouco a pouco, um travelling out revela o restante do elenco que observa o trabalho das atrizes, a mesa com os textos dispostos e o bastidor da cena. Se escuta, novamente, a voz over de Coutinho que proclama as últimas palavras da peça, enquanto o elenco retoma seu ritmo cotidiano de trabalho, comentando a cena, já fora do registro da "encenação-construída".

Através dessa dinâmica de entrada e saída no universo da dramaturgia, Coutinho instiga o espectador a refletir sobre o lugar da representação no teatro, no cinema e nas mais diversas situações sociais. Desdobrando fatores de uma mesma questão, com a "trilogia do palco" o cineasta confronta as nuances nos mecanismos da encenação, em suas diferentes modalidades, e alarga a fenda na barreira que um dia tentou separar os domínios da ficção de do documentário.

\section{BIBLIOGRAFIA}

Andrade, Fábio. 2013. "O Canto dos Mortos - As Canções de Eduardo Coutinho”. In Eduardo Coutinho, organizado por Milton Ohata, 649-657. São Paulo: Cosac Naify/SESC.

Aristóteles. 2000. Poética. São Paulo: Nova Cultural.

Comolli, Jean-Louis. 2008. Ver e Poder - A inocência perdida: cinema, televisão, ficção, documentário. Belo Horizonte: Editora UFMG.

Coutinho, Eduardo. 2008. Encontros - Eduardo Coutinho. Rio de Janeiro: Beco do Azougue.

. 2013. "O Cinema documentário e a escuta sensível da alteridade". In Eduardo Coutinho, organizado por Milton Ohata, 21-47. São Paulo: Cosac Naify/SESC. 
France, Claudine de. 1998. Cinema e antropologia. Campinas: Unicamp.

Goffman, Erving. 2001. Representação do Eu na Vida Cotidiana. São Paulo: Editora Vozes.

. 1986. Frame Analysis: An Essay on the Organization of Experience. Boston: Northeastern University Press.

Naremore, James. 1988. Acting in the Cinema. Berkeley: University of California Press.

Ramos, Fernão Pessoa. 2012. "A Mise-en-scène do Documentário: Eduardo Coutinho e João Moreira Salles”. Rebeca - Revista Brasileira de Estudos de Cinema e Audiovisual, v. 1, n. 1: 16-53.

Stanislavski, Constantin. 2011. A preparação do ator. Rio de Janeiro: Civilização Brasileira.

Xavier, Ismail. 2013. "O Jogo de Cena e as Outras Cenas". In Eduardo Coutinho, organizado por Milton Ohata, 604-627. São Paulo: Cosac Naify/SESC.

\section{FILMOGRAFIA}

Cabra Marcado Para Morrer. Dir. Eduardo Coutinho. Brasil: Eduardo Coutinho Produções Cinematográficas / Mapa Filmes, 1984.

As Canções. Dir. Eduardo Coutinho. Brasil: VideoFilmes, 2011.

Edifício Master. Dir. Eduardo Coutinho. Brasil: VideoFilmes, 2002.

Jogo de Cena. Dir. Eduardo Coutinho. Brasil: Matizar / VideoFilmes, 2007.

Man of Aran. Dir. Robert J. Flaherty. Reino Unido: Gainsborough Pictures, 1934.

Moscou. Dir. Eduardo Coutinho. Brasil: Matizar / VideoFilmes, 2009. 